\title{
Strategies and techniques to enhance constructed wetland performance for sustainable wastewater treatment
}

Haiming $\mathrm{Wu}^{1,2}$, Jinlin Fan ${ }^{3}$, Jian Zhang ${ }^{2}$, Huu Hao Ngo ${ }^{4}$, Wenshan Guo ${ }^{4}$, Shuang Liang ${ }^{2}$, Zhen $\mathrm{Hu}^{2}$, Hai Liu ${ }^{2,5}$

${ }^{1}$ College of Natural Resources and Environment, Northwest A \& F University, Yangling, Shaanxi 712100, People's Republic of China

${ }^{2}$ Shandong Key Laboratory of Water Pollution Control and Resource Reuse, School of Environmental Science \& Engineering, Shandong University, Jinan 250100, People's Republic of China

${ }^{3}$ National Engineering Laboratory of Coal-Fired Pollutants Emission Reduction, Shandong University, Jinan 250061, People's Republic of China

${ }^{4}$ School of Civil and Environmental Engineering, University of Technology Sydney, Broadway, Sydney, NSW 2007, Australia

${ }^{5}$ Department of Chemical and Biomolecular Engineering, University of California, Berkeley, CA 94720, USA

\begin{abstract}
Constructed wetlands (CWs) have been used as an alternative to conventional technologies for wastewater treatment for more than five decades. Recently, the use of various modified $\mathrm{CWs}$ to improve treatment performance has also been reported in the literature. However, the available knowledge on various $\mathrm{CW}$ technologies considering the intensified and reliable removal of pollutants is still limited. Hence, this paper aims to provide an overview of the current development of $\mathrm{CW}$ strategies and techniques for enhanced wastewater treatment. Basic information on configurations and characteristics of different innovations was summarized. Then, overall treatment performance of those systems and their shortcomings were further discussed. Lastly, future perspectives were also identified for specialists to design more effective and sustainable CWs. This information is used to inspire some novel intensifying methodologies, and benefit the successful applications of potential $\mathrm{CW}$ technologies.
\end{abstract}

\section{Keywords}

Constructed wetlands; Wastewater treatment; Enhancing strategies; Intensifying techniques; Sustainable performance

\section{Introduction}

Due to imbalanced development and inadequate investment in water treatment infrastructures, especially in developing countries, large amounts of wastewater containing high levels of various contaminants are discharged into water bodies and further result in 
negative health and environmental consequences (Wu et al. 2011a; Wang et al. 2013). However, conventional wastewater treatment processes are becoming limiting when facing the growing environmental legislation and increasingly more stringent emission standards for pollutants because they are generally expensive and not entirely feasible for widespread application in rural areas (Carty et al. 2008; Rai et al. 2013). Therefore, ecological technologies have been attracting more attention as alternative solutions for wastewater treatment and have been significantly developing in these years (Vymazal 2011; Wu et al. 2015a).

Being one of the widely used ecological technologies, constructed wetland (CW) as a typical and optimal ecological wastewater treatment is a cost-effective and sustainable way for waste treatment (Vymazal 2013; Wu et al. 2014). Thus, CWs have indeed been proven to be efficient for the treatment of conventional (organic matter, nutrients, microorganisms, etc.), nonconventional (such as heavy metals and hydrocarbons), and even emerging pollutants (pharmaceuticals, steroid hormones, biocides, etc.) in a variety of wastewaters such as domestic sewage, agricultural wastewater, industrial effluent, mine drainage, leachate, contaminated groundwater, urban runoff, and raw drinking water worldwide (Vymazal 2011; Verlicchi and Zambello 2014). In the past decades, numerous studies have focused on the design, operation, and performance of CWs. In addition, in order to expand the applications of CWs for wastewater treatment, great research efforts have currently been made for improving the treatment performance of the wetlands and minimizing the effects of different influencing factors (Meng et al. 2014; Yan and Xu 2014). However, the acquired knowledge and information on the sustainability of CW treatment technology are still limited.

On the other hand, although CWs have apparent advantages in energy consumption and economic costs in comparison to WWTP, land requirements for CWs may be the most limiting factor for their application (Wu et al. 2015a). In order to achieve sustainable removal performance and comply with stringent effluent requirements (especially for treating wastewaters with complicated pollution characteristics and variable pollutant loadings under extreme conditions), the development of more appropriate strategies and techniques is of great importance (Huang et al. 2015; Wu et al. 2015a). However, they will increase the life cycle cost of CWs (Wu et al. 2015a). The recent review by Wu et al. (2014) suggested that comprehensive understanding and comparative evaluation on the sustainability of various technologies should be further and extensively investigated. Additionally, there is an urgent need to determine whether or not the strategies and techniques are optimal for high and sustainable treatment performance and benefit the successful application of full-scale CWs.

Therefore, the main objective of this paper is to provide an overview on how to develop the enhancing strategies and techniques for CWs, with a focus on the removal performance and sustainable application for wastewater treatment. Basic information on configurations and characteristics of these strategies and techniques is also briefly reviewed. The overall treatment performance and their sustainability of those systems are further comparatively evaluated and discussed based upon a comprehensive dataset collected from publications. Future perspectives are also identified for the enhancement of $\mathrm{CW}$ treatments. 


\section{Strategies for enhancing performance in CWs}

The treatment performance of $\mathrm{CW}$ commonly depends on the optimization of various operating and environmental conditions. Therefore, potential strategies and methods have been employed to $\mathrm{CW}$ systems and achieve the high and stable removal performance with lower life cycle cost (Wu et al. 2014). Currently applied enhancing strategies for CWs include (a) thermal insulation, (b) tidal flow operation, (c) step-feeding, (d) effluent recirculation, (e) supply of external carbon sources (addition of organic carbon and application of organic substrates), (f) harvest of biomass, (g) bioaugmentation, and (h) addition of earthworms (Fig. 1 and Table S1).

\section{Thermal insulation}

The overall removal performance of CWs is attributed to a variety of physical, chemical, and biological removal mechanisms. However, the primary removal of most pollutants due to microbial transformations is highly dependent on the temperature condition of CW (Meng et al. 2014). Thus, the design approach of thermal insulation was introduced by some scientists and engineers to maintain the operation and long-term performance in a cold climate. The subsurface flow (SSF) CW, as one of the typical traditional types of CWs, is more suitable for winter and/or cold climate applications because the insulating air layer between the ice cover and subsurface water level minimizes the energy losses through evaporation and convection during the treatment process (Wallace et al. 2001). Nevertheless, this type of wetland with only ice cover is often inefficient for achieving the satisfactory treatment performance in cold conditions. Therefore, the CWs covered with the insulating mulch materials have been designed to prevent freezing and further enhance pollutant removal performance (Wallace et al. 2001). Various mulch materials such as bark, agricultural straw, pine straw, wood chips, plastics, and waste compost have been used (Wallace et al. 2001; Yan and $\mathrm{Xu}$ 2014). Wu et al. (2011b) developed an integrated household CW with an integral insulating layer of 40-cm wood chips to treat household domestic wastewater in rural villages in northern China. This insulating biomass layer could maintain bed temperature above $6{ }^{\circ} \mathrm{C}$ and provide significant system thermal insulation. As a result, a high treatment performance (biochemical oxygen demand (BOD) $95 \%$, total suspended solids (TSS) $96 \%$, ammonia nitrogen $\left(\mathrm{NH}_{4}{ }^{+}-\mathrm{N}\right) 84 \%$, and total phosphorus (TP) $88 \%$, respectively) was obtained in freezing winter $\left(-8{ }^{\circ} \mathrm{C}\right)$. Similarly, in an insulation-aerated $\mathrm{CW}$ covered by mulch layer, the average removal efficiencies of BOD, chemical oxygen demand (COD), and $\mathrm{NH}_{4}{ }^{+} \mathrm{N}$ (88, 44 , and $93 \%$, respectively) were dramatically improved when air temperature was as low as $-26{ }^{\circ} \mathrm{C}$ (Nivala et al. 2007). It was also suggested that a good mulch material must be properly selected. In order to sustain the $\mathrm{CW}$ for wastewater treatment in extreme frigid climate, a full-scale greenhouse-structured wetland system has been investigated for improving the removal of pollutants (Gao and $\mathrm{Hu}$ 2012). The performance of the system showed that the mean removal efficiencies of COD, $\mathrm{NH}_{4}{ }^{+}-\mathrm{N}$, and TP were 58, 27, and $28 \%$, respectively, and even the minimum ambient air temperature decreased up to $-30{ }^{\circ} \mathrm{C}$. 
However, the construction of greenhouse for insulation in winter led to an increase in investment costs.
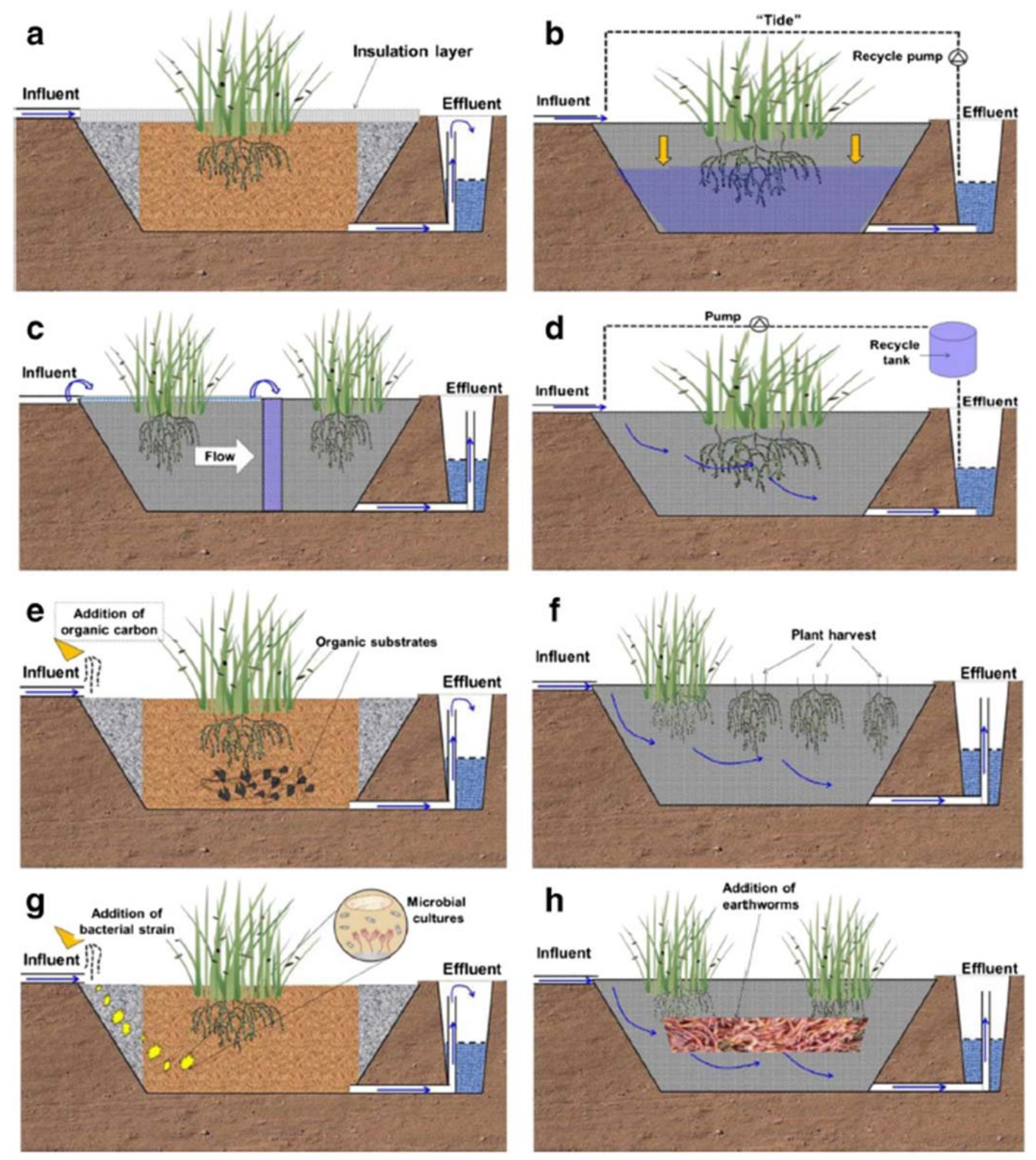

Fig. 1 Configurations of various enhancing strategies used in $\mathrm{CW}$ wastewater treatments.

a thermal insulation, b tidal flow operation modified from Zhao et al. (2004), c step-feeding modified from Wu et al. (2014), d effluent recirculation modified from Sun et al. (2003), e supply of external carbon sources, $\mathbf{f}$ harvest of biomass, $\mathbf{g}$ bioaugmentation, and $\mathbf{h}$ addition of earthworms 


\section{Tidal flow operation}

For treatment wetlands, oxygen is a crucial environmental parameter that controls nitrification and biodegradation of organics. Particularly, when CWs are used to treat highstrength wastewaters, uncertainties affecting the reliability of treatment performance often arise due to the oxygen transfer limitations ( $\mathrm{Wu}$ et al. 2011c). Thus, a new tidal flow operation strategy (also commonly known as the fill-and-drain operation) has been proposed. As CW fills and drains, the $\mathrm{CW}$ bed is intermittently saturated, and air drawn into the aggregate rapidly oxygenates biofilms (Jia et al. 2010). The tidal flow operations as the potential method of improving treatment efficiency were investigated in various studies and projects (Zhao et al. 2004; Jia et al. 2010). The typical literature-reported applications of tidal operational strategy in CWs are summarized in Table S1, and most studies on tidal flow wetlands have been carried out in lab-scale trials. Oxygen transfer capacity and the removal of $\mathrm{NH}_{4}{ }^{+}-\mathrm{N}$ and organic matter in a lab-scale tidal flow $\mathrm{CW}$ were evaluated by $\mathrm{Wu}$ et al. (2011c). The maximum removal of $\mathrm{BOD}, \mathrm{NH}_{4}{ }^{+}-\mathrm{N}$, and total nitrogen (TN) for various pollutant loadings (BOD loading $174-330 \mathrm{~g} / \mathrm{m}^{2} /$ day) was 91,82 , and $43 \%$, respectively. Sun et al. (2006) studied a pilot-scale CW for high-strength piggery wastewater treatment using tidal flow operation. They concluded that the system showed an obvious polishing effect, and the removal efficiencies of COD, BOD, $\mathrm{TSS}, \mathrm{NH}_{4}{ }^{+}-\mathrm{N}$, and TP were $80,82,78,58$, and 45 $\%$, respectively, which were considerably higher than conventional subsurface flow systems. Nevertheless, the removal performance by using this strategy depends on many factors, such as flood drain ratios, $\mathrm{C} / \mathrm{N}$ ratio, and substrate characteristics. Sun et al. (2007) reported on the effect of different medium arrangement in tidal flow CWs treating pig farm wastewater, and the results demonstrated that employing coarse substrates in the upper layer of the systems could improve the removal of organic matter and suspended solids, due to less clogging problem. In addition, Chang et al. (2014) investigated the influence of different flooded/drained (F/D) time ratios on nitrogen transformations in tidal flow CWs. The authors indicated that longer drained and shorter flooded time gave a positive effect on nitrification in wetlands, but F/D time ratios had a little influence on phosphorus removal. Zhi and Ji (2014) reported that high COD (83-95\%), $\mathrm{NH}_{4}{ }^{+}-\mathrm{N}$ (63-80\%), and TN (50-82\%) removal efficiencies were achieved in a novel tidal flow $\mathrm{CW}$ under the $\mathrm{C} / \mathrm{N}$ ratios ranging from 2 to 12. The results also showed that the $\mathrm{C} / \mathrm{N}$ ratio greater than 6 was required to achieve complete denitrification. Although these studies provided some promising results in terms of removal of pollutants, a better understanding of tidal flow operation and its practicability requires further full-scale investigation.

\section{Step-feeding}

During the treatment in $\mathrm{CWs}$, TN removal could not be desirable because of carbon deficiency during biological denitrification, particularly for wastewaters with high nitrate and low organic matter (e.g., sewage drainage) (Hu et al. 2012a; Wu et al. 2014). The stepfeeding strategy, as an effective option, can enhance the process of denitrification with the 
additional carbon source supply by introducing the gradational inflow of wastewater into CWs. In addition, it can utilize the whole wetland surface area more effectively, by distributing the wastewater inflow at more than one input points along the wetland length (Stefanakis et al. 2011). In recent years, the effect of the step-feeding method has been comprehensively evaluated by some researchers (Stefanakis et al. 2011; Hu et al. 2012a; Li et al. 2014a). The performance of pilot-scale horizontal flow (HF) CWs with different stepfeeding schemes (33:33:33 and 60:25:15) was investigated by Stefanakis et al. (2011). They found that the treatment efficiency of CWs with step-feeding operation could be greatly improved, and the removal efficiencies of BOD, $\mathrm{COD}, \mathrm{NH}_{4}{ }^{+}-\mathrm{N}, \mathrm{TN}$, and TP accounted for $91,90,91,80$, and $84 \%$, respectively. Hu et al. (2012a) also extensively studied step-feeding strategy to enhance biological nitrogen removal in a tidal flow $\mathrm{CW}$, and the results indicated that enhanced TN removal of $83 \%$ was achieved under a high nitrogen loading rate of $19.1 \mathrm{~g}$ $\mathrm{N} / \mathrm{m}^{2} /$ day. Additionally, a comparison study of vertical flow (VF) CWs treating swine wastewater at four different shunt ratios was carried out by Wang et al. (2014a). The results showed that the shunt ratio had a significant influence on nitrogen removal in CWs, whereas it had no obvious impact on COD, BOD, TSS, and TP removal. Even though the published literature reported that the adoption of wastewater step-feeding in CWs might be feasible if an appropriate scheme was selected, the design/operation parameters on this strategy should be further optimized to make it much more attractive.

\section{Effluent recirculation}

In order to enhance the treatment performance of CWs, especially for treating high-strength wastewaters, an operation known as effluent recirculation has been employed in some studies (Sun et al. 2003; Zhao et al. 2004; Lavrova and Koumanova 2010; Foladori et al. 2013). The concept of this alternative strategy is that a part of the effluent extracted from the outflow of the system is transferred back to the inflow of the system. This operation can enhance interactions between pollutants and microorganisms on the roots of plants and the surface of substrates due to additional oxygen for aerobic microbial activities and a longer retention time (Zhao et al. 2004). Several studies have been conducted to investigate the treatment of high-strength wastewater in various kinds of CWs including HF CWs, VF CWs, and tidal flow CWs. Effluent recirculation was investigated in a VF system treating an agricultural wastewater (Sun et al. 2003). The removal efficiencies of BOD, COD, $\mathrm{NH}_{4}{ }^{+}-\mathrm{N}$, and TSS increased to $96,77,74$, and $91 \%$ after recirculation was adopted, but the operation only slightly increased the removal percentage of $\mathrm{PO}_{4}-\mathrm{P}$. Lavrova and Koumanova (2010) also evaluated the removal performance of a lab-scale VF CW to treat landfill leachate in the northwestern region of Bulgaria using different recirculation ratios; $96 \%$ for COD, $92 \%$ for BOD, and $100 \%$ for $\mathrm{NH}_{4}{ }^{+}-\mathrm{N}$ and TP were removed at the recirculation ratio of $1: 3$. Similarly, Prost-Boucle and Molle (2012) reported the use of recirculation on a single French vertical flow $\mathrm{CW}$ to replace the classical French vertical flow CWs, which indicated the positive effect of recirculation on the performance enhancement of CWs. Moreover, the application of recirculation in hybrid CWs (combination of different kinds of CW systems) 
has been proven to be effective in enhancing TN removal (Ayaz et al. 2012). It was also reported that the use of recirculation in CWs depends on influent loads (Foladori et al. 2013). Effluent recirculation may cause problems in HF CWs due to the increased hydraulic load. On the other hand, in full-scale operating facilities, this operation may also increase operation costs because of additional energy consumption for pumping.

\section{Supply of external carbon sources}

In treatment wetlands, the nitrate removal mechanism is mainly biological denitrification (possible plant uptake and denitrification). As the main mechanism for removing nitrate, denitrification reactions need an electron donor, such as organic carbon, which is often lacking in CWs. The carbon source in CWs generally comes from wastewater, sediments, and the rhizodeposition products of plants (Zhai et al. 2013). Therefore, to improve denitrification efficiency in CWs, external sources of carbon have usually been added into wetland systems, and the added carbon source (mainly organic carbon and organic substrates) has also been proven to have significant effects on nitrogen removal in CWs (Wu et al. 2014).

\section{Addition of organic carbon}

To date, various organic carbon sources, such as glucose, fructose, sodium acetate, methanol, starch, cellulose, and some waste products, have been employed in CWs (Meng et al. 2014). Lin et al. (2002) investigated the effects of externally added organic matter on nitrate removal in CWs treating groundwater, and the results showed that adding fructose to the systems improved the nitrate removal significantly (>90\%). Rustige and Nolde (2007) employed acetic acid as the source of organic carbon in CWs for landfill leachate treatment and reported optimum denitrification rates (75\%). In addition, Lu et al. (2009) studied the effect of carbon source on denitrification in CWs and found that the nitrate removal was improved to be $60 \%$ when glucose was added. However, a significant fraction of the added organic carbon could not be utilized by the denitrifiers and might be consumed by other microbial processes (e.g., oxidation) in CWs because low molecular carbohydrates are usually degraded easily in water. Thus, a less labile and low-cost carbon source such as leachate from litter decomposition of plants would be an alternative. Chen et al. (2011) used individual batch wetlands to evaluate the relation between litter-derived carbon sources and denitrification. The results indicated that much higher denitrification rates $(>90 \%)$ were observed when using anaerobic litter leachate (from Typha latifolia) as the carbon source.

\section{Application of organic substrates}

Employing low-cost and stable carbon source for enhancing denitrification in CWs has been explored to reduce the cost of treatment. Solid organic materials rich in organic carbon are the possible alternatives. To date, various unconventional wetland substrates (such as eucalyptus wood mulch, palm tree mulch, pine bark, sugarcane bagasse, rice husk, wheat straw, maize cobs, peat, and synthetic polymers) have been used to optimize nitrogen 
removal from wastewater (Wang et al. 2010; Saeed and Sun 2011, 2013; Shen et al. 2015; $\mathrm{Wu}$ et al. 2015a). A comparative study on the removal of nutrients and organics in CWs employing organic media (organic wood mulch) was conducted by Saeed and Sun (2011), and the results indicated that wetlands with organic substrate achieved higher removals of $\mathrm{NH}_{4}-\mathrm{N}(99 \%)$, TN $(97 \%)$, TP (60\%), and BOD (71\%). In another study by Saeed and Sun (2013), the organic sugarcane bagasse was used for treating textile wastewater. It was found that simultaneous removals of BOD $(79 \%)$ and $\mathrm{NH}_{4}-\mathrm{N}(66 \%)$ were obtained in the firststage wetlands. In a recent study, Shen et al. (2015) reported the use of cornstarch/polycaprolactone (SPCL) blends as solid carbon source in CWs to enhance nitrate removal. The results showed that the high nitrate removal efficiency $(98 \%)$ was attained, and denitrifying bacteria Bacillus and Thauera were very abundant in the biofilm attached on the surface of SPCL. However, a potential problem of employing organic substrates may increase the concentration of COD in the effluent of CWs as compared to systems with gravel media (Saeed and Sun 2011).

\section{Harvest of biomass}

Wetland plants are considered to be an essential component of CWs and play an important role in CWs. It has been well documented that planted CWs are more efficient in wastewater treatment than those without vegetation because plants not only directly take up pollutants but also enhance removal processes by increasing environmental diversity in the rhizosphere (Vymazal 2011). However, it should been noted that the plant contribution to nutrient removal is only transitory, and re-release of nutrients from decomposing vegetation is inevitable due to plant senescence (Zhu et al. 2012a). Many investigations employing plant harvesting strategy for increasing pollutant removal in CWs have been reported in different regions. A review from Saeed and Sun (2012) indicated that plant harvesting can also improve $\mathrm{N}$ removal in CWs, particularly for lightly loaded systems. Zhu et al. (2012b) studied the nutrient removal and the effects of plant harvesting in a pilot-scale natural wetland. The results showed that harvest of aboveground plants had a beneficial effect on removal capacity, especially for $\mathrm{TN}$ and $\mathrm{NH}_{4}{ }^{+}-\mathrm{N}$, compared with that without harvesting. The results by Brezinová and Vymazal (2015) revealed that if inflow and outflow zones in CWs were harvested separately during different periods of the growing season, the amount of nitrogen and phosphorus removed via harvesting increased up to 42 and $43 \%$, respectively, as compared to a single harvest of the whole surface of the systems. Moreover, Vymazal et al. (2010) evaluated the role of multiple harvest of aboveground biomass for trace element removal in $\mathrm{CWs}$ receiving municipal sewage and indicated that for those elements (As, $\mathrm{Ba}$, $\mathrm{Co}, \mathrm{Cr}, \mathrm{Cu}, \mathrm{Fe}, \mathrm{Ga}, \mathrm{Hg}, \mathrm{Mn}, \mathrm{Ni}, \mathrm{Pb}, \mathrm{Sb}$, and $\mathrm{U}$ ), multiple harvest could be beneficial for element removal from wastewater. These results can be useful for the plantation design and the management of vegetation in CWs, as well as could be good at maintaining the desirable plant density for optimal operation and maintenance. Nevertheless, optimization of the harvesting strategy needs further investigations aiming at enhancing the performance of pollutant removal because an appropriate plant harvesting strategy is associated with plant 
species, growth stages, times of harvest, the density of harvested biomass, parts of CWs, and climatic conditions.

\section{Bioaugmentation}

Microbial degradation, which involves a complex series of biochemical reactions and varies with the microorganisms involved, is a key removal process of pollutants in CWs. To improve the treatment performance, the strategy of bioaugmentation, namely the addition of highly concentrated and specialized microbial cultures, has been introduced into CWs in recent years (Meng et al. 2014). The commonly applied options in this strategy mainly involve the addition of a pre-adapted pure bacterial strain or consortium and the introduction of genetically engineered bacteria. It has been reported that bioaugmentation is a suitable way for accelerating the biodegradation rate in CWs treating various wastewaters even containing toxic contaminants (Zhao et al. 2014; Meng et al. 2014). The effect of the addition of Bacillus subtilis FY99-01 strains on nitrate removal in a riparian wetland was investigated by Pei et al. (2010). Results indicated that B. subtilis FY99-01 efficiently enhanced denitrification with a maximal nitrate removal of $36 \%$. Similarly, nutrient removal in CWs added with a consortium of six denitrifying bacteria for treating polluted river water was evaluated by Shao et al. (2014). The removal efficiencies were found to be $75 \%$ for COD, $96 \%$ for TN, $96 \%$ for $\mathrm{NH}_{4}{ }^{+}-\mathrm{N}$, and $90 \%$ for TP. In addition, Zhao et al. (2014) evaluated the effects of bioaugmentation on endosulfan removal in CWs and indicated that after 20 days of bioremediation experiment, endosulfan removal efficiency was increased to 89-97\%. Although the above research on bioremediation demonstrated their effectiveness in contamination removal, finding competent strains with high removal efficiency and optimizing their conditions are essential needs to study for the successful application of this strategy in the future (Zhao et al. 2014).

\section{Addition of earthworms}

Currently, subsurface flow (SSF) CWs, as a promising technology for decentralized wastewater treatment, have been applied widely in rural areas. Nevertheless, one of the major problems for the efficient use of SSF CWs is the clogging due to the solid contents in wastewater, which in turn lower the design loading rate and treatment performance (Hua et al. 2013). Alternatively, adding earthworms can be a potential method. It was reported that earthworms can directly ingest and digest organic materials, but also influence nitrogen

cycling indirectly (Xu et al. 2013a). Currently, they are applied in CWs to treat wastewater due to their important function in matter cycling (such as $\mathrm{C}, \mathrm{N}$, and $\mathrm{P}$ ). Wu et al. (2013) demonstrated that average removal efficiencies of $\mathrm{COD}, \mathrm{NH}_{4}{ }^{+}-\mathrm{N}$, and $\mathrm{TN}$ in the earthwormamended wetlands were 15,21 , and $20 \%$, respectively, which were higher than those observed in control wetlands. Similarly, it was reported that adding earthworms to the CW increased the TN and TP removal efficiencies by 10 and $7 \%$, respectively (Xu et al. 2013b). In another study of applying earthworms to SF CWs for treating swine wastewater, 
earthworms were found to help reduce sludge production on the surface of wetlands $40 \%$ by volume, which lowered the cost of treating the sludge (Nuengjamnong et al. 2011). However, for further practical use, more investigation should been conducted regarding the effect of the earthworms, especially its mechanisms for pollutant removal.

\section{Techniques to intensify performance of CWs}

Although treatment wetlands have been widely studied and exploited for removal of pollutants from various wastewaters, the removal of nutrients does not meet the environmental standards ( $\mathrm{Li}$ et al. 2014b). In addition, the research challenge of $\mathrm{CW}$ is to successfully extend its application to strong or high-strength effluents, e.g., livestock wastewater and landfill leachate (Vymazal 2014). To achieve higher and sustainable purification rates, a great variety of intensified $\mathrm{CW}$ treatments, including wetland systems integrated with other technologies, wetlands with novel configuration, and wetlands combined with other wastewater treatment systems, have been developed in recent years (Vymazal 2013; Meng et al. 2014; Yan and Xu 2014; Wu et al. 2014). To date, the most widely used techniques to intensify the performance of CWs are summarized in Fig. 2 and Table S2, and the details of current advances have also been provided in the following sections.

\section{Towery hybrid CW}

CWs can be categorized into free water surface (FWS) CWs and SSF CWs according to the wetland hydrology, and SSF CWs can be further divided into VF and HF CWs (Wu et al. 2015a). A combination of VF and HF systems, known as hybrid wetlands, can also be increasingly employed for the treatment of wastewater at the end of the twentieth century (Vymazal 2013). In hybrid systems, an effective COD and TN removal can be achieved because various types of wetland (SSF and FWS) systems provide their respective advantages, such as sufficient oxygen diffusion and enough carbon source which results from individual feeding mode and flow regime in CWs (Vymazal 2013). Unlike the common hybrid $\mathrm{CW}$, a novel towery hybrid $\mathrm{CW}$ has been designed for enhancing nitrogen removal from domestic wastewater (Ye and $\mathrm{Li}$ 2009). This system consists of the first- and third-stage rectangular HF CW and second-stage circular three-layer FWS CW with various diameters. The results revealed that high removal efficiencies for TSS, COD, $\mathrm{NH}_{4}{ }^{+}-\mathrm{N}, \mathrm{TN}$, and TP were achieved $(89,85,83,83$, and $64 \%$, respectively), which could be improved by passive aeration of a tower-type cascade overflow from the upper layer into the lower layer in the second stage and additional organic matter supplied from the bypass of influent into the second stage of hybrid CW (Ye and Li 2009). Similarly, the towery hybrid system with threelevel stage VF CWs was designed to treat livestock wastewater, and the results indicated that average removal rates for towery hybrid CWs were $62 \%$ for COD, $86 \%$ for SS, and $>95 \%$

for $\mathrm{NH}_{4}{ }^{+}-\mathrm{N}$ and for TP that were slightly higher than the removal rates for the ladder-type hybrid CWs in long-term operation (Zhu et al. 2012a). 

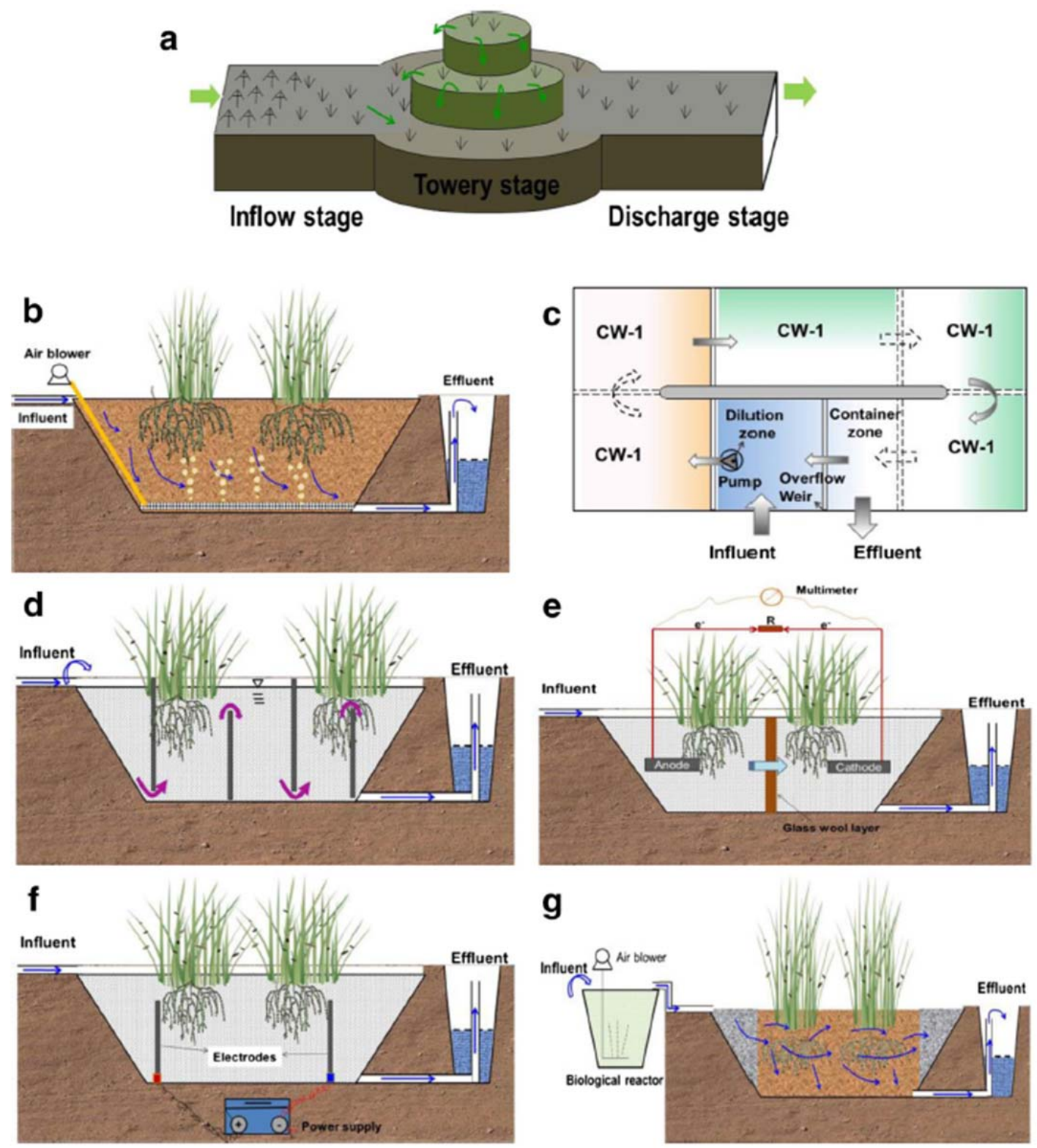

Fig. 2 Schematics and various enhancing techniques applied in $\mathrm{CW}$ wastewater treatments.

a Towery hybrid CW modified from Wu et al. (2014), b artificial aeration CW modified from Wu et al. (2014), c circular flow corridor CW modified from Peng et al. (2012), d baffled subsurface flow CW modified from Wu et al. (2014), e microbial fuel cell CW modified from Villaseñor et al. (2013), f electrolysis-integrated CW modified from Ju et al. (2014a), and g biological reactor-combined CW modified from Bilgin et al. (2014)

\section{Artificial aeration CW}

Nitrification, as the limiting step of biological nitrogen especially in SSF CWs, usually requires large quantities of available oxygen. However, most conventional CWs fail to fulfill 
this key step due to insufficient oxygen supply (Hu et al. 2012b). An aerobic condition for nitrification can generally be achieved by oxygen release of plants, oxygen transfer via intermittent loading, and diffusion via fill-and-drain operation or other means. Nevertheless, in order to increase the applied wastewater loads or to meet advanced treatment standards, sufficient oxygen must be provided to the nitrifying microbes in CWs (Wu et al. 2015b). Artificial aeration wetland systems appear to be an alternative that supplement oxygen for effective nitrification. It is also reported that artificial aeration CWs, which are installed air distribution lines at the base of the systems to increase the oxygen transfer rate, have higher $\mathrm{N}$ removal performance than CWs without artificial aeration (Wu et al. 2014).

\section{Continuous aeration $\mathrm{CW}$}

Artificial aeration can mainly be classified as continuous aeration and intermittent aeration. For continuous aeration, considerable efforts have been made to improve pollutant removal efficiency in SSF CWs treating various wastewaters. Ong et al. (2010) investigated the supplementary aeration on the simultaneous removal of organics and nutrients and showed that the artificial aeration (flow rate $1.04 \mathrm{~mL} / \mathrm{min}$ ) increased the aerobic biodegradation of organic matter and nitrification (COD $94 \%$ and $\mathrm{NH}_{4}{ }^{+}-\mathrm{N} 98 \%$ ) in VF CWs. Similarly, continuously aerated VF CWs operating at different hydraulic loading rates (HLRs) were evaluated for heavily polluted river water treatment (Dong et al. 2012), and the maximal removal efficiencies for $\mathrm{COD}, \mathrm{NH}_{4}{ }^{+}-\mathrm{N}$, and $\mathrm{TP}(81,87$, and $37 \%$, respectively) were observed at the HLR of $19 \mathrm{~cm} /$ day. The efficacy of this approach has also been shown at fullscale HF CWs by Butterworth et al. (2013), and the results demonstrated enhanced nitrification in the aerated bed with $99 \%$ mass removal up to the maximum loading rate of $10.1 \mathrm{~g} \mathrm{NH}_{4}{ }^{+}-\mathrm{N} / \mathrm{m}^{2} /$ day. Moreover, Li et al. (2014b) introduced artificial aeration into threestage HF CWs to improve the efficiency of sewage water purification and showed that the removal efficiencies of $\mathrm{COD}, \mathrm{NH}_{4}{ }^{+}-\mathrm{N}$, and $\mathrm{TN}$ in systems with front and rear aeration and anoxic treatment were 90, 99, and $51 \%$, respectively. Although continuous aeration CWs have been performed successfully in pollutant removal, denitrification efficiency with regard to nutrient removal is still low (Wu et al. 2014). Moreover, increasing energy inputs to CWs with continuous mode could remain questionable and greatly inhibit its application (Fan et al. 2013a).

\section{Intermittent aeration $\mathrm{CW}$}

Denitrification, as an anaerobic and heterotrophic microbial process, can usually be limited in CWs by carbon availability, although it is generally not the limiting step in nitrogen removal. In addition, excessive oxygenation resulting from artificial aeration could lead to nitrate accumulation via incomplete denitrification in particular and negatively affect $\mathrm{TN}$ removal (Wu et al. 2014, 2015b). Therefore, intermittent aeration in CWs could be preferable to the continuous mode due to providing proper spatial aerobic and anoxic conditions for simultaneous nitrification and denitrification. Numerous studies on laboratory- and pilot-scale SSF CWs have proven that this approach is an effective and economic solution to achieve 
high TN removal. Fan et al. (2013b) found that about $90 \%$ of ammonium $\left(3.5 \mathrm{~g} / \mathrm{m}^{2} /\right.$ day $), 80$

$\%$ of TN $\left(3.3 \mathrm{~g} / \mathrm{m}^{2} /\right.$ day $)$, and $90 \%$ of organic pollutants $\left(29.3 \mathrm{~g} / \mathrm{m}^{2} /\right.$ day $)$ were removed by using intermittent aeration SSF CWs to treat decentralized rural sewage. Foladori et al. (2013) also reported on the use of intermittent artificial aeration in pilot-scale VF CWs to treat high hydraulic and organic loads, and a higher removal performance was observed for COD, TN, and even TP. Moreover, a side-by-side comparison of two VF CWs with intermittent aeration and continuous aeration was conducted by Boog et al. (2014), and their results showed that intermittent aeration not only improved treatment performance for $\mathrm{TN}$ but also saved $33 \%$ of running energy cost for aeration. Although the function of intermittent aeration in terms of increasing pollutant removal efficiency is significantly obvious in labscale and pilot-scale studies, further research on full-scale $\mathrm{CWs}$ is still required.

\section{Circular flow corridor $\mathrm{CW}$}

If the conventional CWs were directly used for the treatment of high-strength industrial wastewater, some operational problems, such as the inhibition of high pollutant concentration on plants and poor nitrification due to oxygen exhaustion for large amounts of organic matter degradation, may occur (Vymazal 2014). Therefore, in view of the benefit of the partial recirculation of wastewater within wetlands for enhancing removal of nitrogen, a novel circular flow corridor $\mathrm{CW}$ has been promoted for the secondary treatment of swine wastewater (Peng et al. 2012). This CW consisted of several compartments and was connected in an annular corridor. Along the water flowing direction, the water flowed through the dilution zone, the porous media zone, and the container zone in sequence. Through the special intercirculation of wastewater in the system, the high-strength swine wastewater could be purified successfully, and high removal efficiencies of above $93 \%$ for $\mathrm{COD}, \mathrm{NH}_{4}{ }^{+}-\mathrm{N}$, and TP were achieved at low temperature. In addition, the internal circular flow mode could delay the clogging of wetland porous media and improve the utility of released $\mathrm{Ca}^{2+}$ and $\mathrm{Mg}^{2+}$ from zeolite media. Nevertheless, the authors pointed out that longterm efficacy and stability of the circular flow corridor CW needed to be evaluated in pilotscale systems toward the treatment of real wastewater.

\section{Baffled subsurface flow CW}

Although the hybrid CWs improved the treatment performance especially for removal of nitrogen and organics, these systems have some limitations such as requirement of a large land area and a recycling system (Vymazal 2013). Considering these drawbacks, a novel baffled SSF CW has currently been developed (Tee et al. 2012). This design was based on the traditional HF CW with increasing baffle through the up and down flow sequentially to make wastewater flow through the wetland beds. Thus, the pollutant removal efficiency was improved under multiple aerobic, anoxic, and anaerobic conditions sequentially in CWs. As shown by Tee et al. (2012), the planted baffled wetland achieved $79 \% \mathrm{COD}, 99 \% \mathrm{NH}_{4}{ }^{+}-\mathrm{N}$, and $100 \%$ total oxidized nitrogen (TON) removal at a HRT of 5 days. Moreover, domestic 
wastewater purification of different types of baffled SSF CWs was investigated by Cui et al. (2013). Results showed that the maximum removal efficiencies in different baffled wetlands were 94-99\% for COD, 95-99\% for $\mathrm{NH}_{4}{ }^{+}-\mathrm{N}, 72-86 \%$ for TN, and $94-99 \%$ for TP. It has also been reported that the baffled HF CW was used to treat domestic wastewater containing azo dye (Tee et al. 2015). Based on previous experimental research, the full-scale two-stage baffled surface flow $\mathrm{CW}$ covering an area of $7500 \mathrm{~m}^{2}$ was built to purify river water, and the operation of 2 years demonstrated that the system improved the water quality steadily (Wang et al. 2012). Apart from removal performance improvement, this wetland design needs further modification, when operated under adverse conditions (i.e., hydraulic loading fluctuation and seasonal variation).

\section{Microbial fuel cell CW}

Microbial fuel cell (MFC) wastewater treatment has recently appeared as a sustainable technology that can be used to control environmental pollution while producing renewable energy from organic wastes by converting chemical energy into electrical energy during wastewater treatment (Puig et al. 2012). This technology is based on a conventional MFC consisting of aerobic (cathode) and anaerobic (anode) chambers separated by a proton exchange membrane. Recently, some ingenious designs have been developed incorporating/embedding MFCs into other wastewater treatments such as ecological engineering technology. Typically, the CWs combined with MFCs were firstly investigated in dye wastewater treatment by Yadav et al. (2012), making the wastewater treatment system more economical and eco-friendly. Although this novel MFC CW has drawn great attention of scientists, only few studies were found in the literature to date. A microbial fuel cellcoupled CW system (planted with and without Ipomoea aquatica) was used for azo dye decolorization and electricity production (Fang et al. 2013). The results indicated that the planted CW-MFC system achieved the highest decolorization rate of about $91 \%$ and a voltage output of about $610 \mathrm{mV}$. Furthermore, two CW-MFCs with different operating modes (batch and continuous) have been constructed to treat swine wastewater, and an average of 71-76\% COD removal with a peak electrical energy of $9.4-12.83 \mathrm{~mW} / \mathrm{m}^{2}$ was achieved (Zhao et al. 2013). Specifically, a HF CW acting simultaneously as a MFC was operated for treating domestic wastewater with increasing organic loading rates, which indicated that high organic loading rates could cause the MFC system to stop working (Villaseñor et al. 2013). Therefore, more attention should be paid to the CW-MFC operation, especially the adverse effects on the wastewater treatment ability of CWs by combining MFC technology.

\section{Electrolysis-integrated CW}

The electrochemical method has been successfully utilized to treat wastewater. Coagulants are formed in situ by the electrodissolution of sacrificial anodes typically composed of iron or aluminum (Cañizares et al. 2007). This electrocoagulation process can be efficient particularly for phosphorus removal. Moreover, the chemical reaction proceeds at the cathode 
and also produces hydrogen gas which could be an electron donor for autotrophic denitrification under a low carbon source condition (Lee et al. 2010). Considering a good development potential of the electrolysis technology, electrolysis was thus coupled with CW technology to fully utilize their advantages (Ju et al. 2014a, b). A novel electrolysisintegrated $\mathrm{CW}$ with tidal operation was developed to intensify nitrogen and phosphorus removal ( $\mathrm{Ju}$ et al. 2014a). The results indicated that $\mathrm{COD}, \mathrm{NH}_{4}{ }^{+}-\mathrm{N}$, and TP removals of up to 95, 80, and $90 \%$ were achieved, and electrolysis integration in CWs enhanced the phosphorus removal significantly. However, no significant improvement of TN was shown due to the introduction of electrolysis which may play a vital role on nitrogen transformations especially for lower $\mathrm{C} / \mathrm{N}$ wastewaters ( $\mathrm{Ju}$ et al. 2014a). In another study, a similar electrolysis-integrated tidal $\mathrm{CW}$ was developed to investigate how it intensified nutrient removal and odor control (Ju et al. 2014b). The results revealed that electrolysis integration not only exerted a positive effect on phosphorus removal but also effectively inhibited sulfide accumulation for odor control. No significant difference was found in the microbial communities and abundance in different experimental CWs. Similarly, a novel pilot-scale electrochemical oxidation integrated with the $\mathrm{CW}$ hybrid system has been developed for treating polluted river water by Wang et al. (2014b), and the steady effluent quality (i.e., $\mathrm{NH}_{4}{ }^{+}-\mathrm{N}, \mathrm{TN}, \mathrm{COD}$, and BOD meeting discharge requirements) was achieved especially in winter or spring. However, apart from the abovementioned examples, a profound investigation of this electrolysis-integrated $\mathrm{CW}$ must be conducted. Further research focusing on specific pollutant removal should also be developed.

\section{Biological reactor-combined CW}

A novel design for $\mathrm{CWs}$ combining the conventional wastewater treatment processes such as activated sludge and anaerobic sludge reactors has been developed as hybrid systems to enhance pollutant removal (Lin et al. 2012; Verlicchi et al. 2013; Bilgin et al. 2014). This design usually is composed of the biological system followed by the $\mathrm{CW}$ sequentially. Bilgin et al. (2014) reported an activated sludge-VF CW system focusing on removing COD and nitrogen in a sewage of Aksaray. Over a study period of 25 days, the system achieved moderate TN removals with the removal efficiencies in the range of 35 and $59 \%$ at organic loading rates of $940 \mathrm{mg} \mathrm{TN} / \mathrm{m}^{2} /$ day. Moreover, a hybrid system combining an anaerobic baffled reactor (ABR) and a $\mathrm{CW}$ was employed to treat nitrobenzene wastewater by Lin et al. (2012), and the overall performance throughout the long-term operation indicated that nitrobenzene wastewater could be treated efficiently during the combined process of ABR$\mathrm{CW}$. An activated sludge system followed by a HF CW was also investigated for the removal of selected pharmaceuticals from domestic wastewater (Verlicchi et al. 2013). The results suggested that pharmaceutical residues could be dealt with by this kind of tertiary treatment. However, due to the complexity of these systems combining CWs and conventional secondary treatments, further research would be needed to elucidate the dominant removal mechanisms and contributions for the various pollutants, which would be useful for further improving abatement efficiency. 


\section{Conclusions and future perspectives}

With the unique advantages of lower costs and more benefits, $\mathrm{CW}$ treatments have evolved into a reliable wastewater treatment technology for removing pollutants from many types of wastewater during the last five decades of development. Moreover, according to Zhang et al. (2012), the traditional CW was also a typical sustainable technology due to less investment, lower operation costs, less energy consumption, and more ecological benefits except for higher land requirement, as compared to conventional wastewater treatment processes.

Table 1 Advantages and disadvantages of various strategies and techniques in CWs for wastewater treatment

\begin{tabular}{|c|c|c|}
\hline $\begin{array}{l}\text { Types of strategy } \\
\text { and technique }\end{array}$ & Advantages & Disadvantages \\
\hline Thermal insulation & $\begin{array}{l}\text { Sustained operation in winter for } \\
\text { temperate zones }\end{array}$ & $\begin{array}{l}\text { The construction for the insulation } \\
\text { would increase the investment costs. }\end{array}$ \\
\hline Tidal flow operation & $\begin{array}{l}\text { Lower capital and operation costs than } \\
\text { aerated systems }\end{array}$ & Clogging problem may occur. \\
\hline Step-feeding & $\begin{array}{l}\text { More effective utilization of the whole } \\
\text { wetland surface area and avoiding rapid } \\
\text { clogging }\end{array}$ & $\begin{array}{l}\text { The second pollution of the treated } \\
\text { effluent could arise. }\end{array}$ \\
\hline $\begin{array}{l}\text { Effluent } \\
\text { recirculation }\end{array}$ & $\begin{array}{l}\text { Enhancing the performance especially } \\
\text { for treating high-strength wastewaters }\end{array}$ & More energy for pumping \\
\hline $\begin{array}{l}\text { Supply of external } \\
\text { carbon sources }\end{array}$ & $\begin{array}{l}\text { Significant enhancement of } \\
\text { denitrification }\end{array}$ & $\begin{array}{l}\text { Increasing the costs and potential } \\
\text { problem of increasing the effluent } \\
\text { concentration of organics }\end{array}$ \\
\hline Harvest of biomass & $\begin{array}{l}\text { Increasing environmental diversity and } \\
\text { avoiding a re-release of nutrients from } \\
\text { decomposing vegetation }\end{array}$ & $\begin{array}{l}\text { Optimization of harvesting strategy } \\
\text { may be associated with various } \\
\text { factors. }\end{array}$ \\
\hline Bioaugmentation & $\begin{array}{l}\text { Shortening of the adaptation period and } \\
\text { accelerating the biodegradation rates }\end{array}$ & $\begin{array}{l}\text { The variable performance in full-scale } \\
\text { systems }\end{array}$ \\
\hline $\begin{array}{l}\text { Addition of } \\
\text { earthworms }\end{array}$ & Avoiding the clogging problem & $\begin{array}{l}\text { Ineffective under high influent nutrient } \\
\text { loads }\end{array}$ \\
\hline Towery hybrid CW & $\begin{array}{l}\text { Effective COD and TN removal by } \\
\text { providing their respective advantages of } \\
\text { SSF and FWS CWs }\end{array}$ & More space and land acquisition \\
\hline $\begin{array}{l}\text { Artificial aeration } \\
\text { CW }\end{array}$ & $\begin{array}{l}\text { Effective nitrification by sufficient } \\
\text { oxygen and increasing the applied } \\
\text { wastewater loads }\end{array}$ & More energy inputs \\
\hline $\begin{array}{l}\text { Circular flow } \\
\text { corridor CW }\end{array}$ & $\begin{array}{l}\text { Avoiding the adverse effect of low } \\
\text { temperature and delaying the clogging of } \\
\text { systems }\end{array}$ & $\begin{array}{l}\text { The variable long-term efficacy, more } \\
\text { energy for pumping }\end{array}$ \\
\hline $\begin{array}{l}\text { Baffled subsurface } \\
\text { flow CW }\end{array}$ & $\begin{array}{l}\text { Providing multiple aerobic, anoxic, and } \\
\text { anaerobic conditions sequentially in the } \\
\text { same system }\end{array}$ & $\begin{array}{l}\text { Changes in the total slope design } \\
\text { because of the longer water flow path }\end{array}$ \\
\hline $\begin{array}{l}\text { Microbial fuel cell } \\
\text { CW }\end{array}$ & $\begin{array}{l}\text { Producing renewable energy by } \\
\text { converting chemical energy into } \\
\text { electrical energy during wastewater } \\
\text { treatment }\end{array}$ & $\begin{array}{l}\text { High organic loading rates could cause } \\
\text { the system to stop working, and full- } \\
\text { scale application remains difficult. }\end{array}$ \\
\hline $\begin{array}{l}\text { Electrolysis- } \\
\text { integrated CW }\end{array}$ & $\begin{array}{l}\text { Particularly for phosphorus removal and } \\
\text { odor control }\end{array}$ & More energy inputs \\
\hline Biological reactor- & Reducing the clogging & Full-scale application would be \\
\hline
\end{tabular}


The current review indicates that advances on enhancing strategies and techniques employed in CWs have greatly improved the sustainable operation and successful application of this wastewater treatment system. All types of new strategies and techniques exhibited a remarkable intensification in contaminant removal performance such as organics and suspended solids and nitrogen. Nevertheless, it is clear that these innovations, based on the concept of sustainable development defined at Brundtland Commission, will increase the life cycle cost of CWs. Meanwhile, as shown in Table 1, there are also some apparent disadvantages in each enhancing strategy and technique for wastewater treatment. Therefore, in order to enable specialists to design more effective and sustainable CWs, further research and development is necessary. In summary, the following conclusions are drawn:

1. The use of new strategies and techniques to enhance the removal performance in CWs has been increasing rapidly throughout the world. The removal processes of pollutants by such systems have gained substantial attention in recent years. In conventional CWs, the removal of pollutants often relies on a diverse range of physical, chemical, and biological routes and can vitally be influenced by numerous environmental and operational parameters. Nevertheless, it is still unclear which processes and mechanisms play the key role in pollution removal in various types of enhanced CWs, and how those designs shift the internal system environment to favor enhancing removal performance. Future research particularly into elucidating structure and distribution of the related microbial communities and identifying the related microbes which assist in removal processes will help to further optimize the treatment performance of $\mathrm{CW}$ systems. In addition, it is necessary to evaluate the influence of the key operating factors and optimize the designing parameters to stimulate novel removal routes in systems.

2. The recent innovation of $\mathrm{CW}$ technology for performance intensification has been mostly undertaken at a microcosm scale. Moreover, there are still very few long-term studies related to the continuous assessment of $\mathrm{CW}$ performance and operations. Therefore, further research is required to provide more comprehensive and convincing lines of evidence in pilot-scale or full-scale wetland systems. Concerning the complexity and importance of flow patterns in CWs, special attention should be paid to the evaluation of hydraulic behavior in a case study under varying climate conditions. Also, modeling is a powerful technique for understanding contaminant removal processes in CWs; therefore, it is advisable to take into account hydraulic and degradation models during study so as to design better wetland and predict removal performance. Furthermore, in order to increase our understanding of the removal processes in those intensified CWs, there is a need to evaluate the sustainable removal performance based on long-term monitoring for water quality.

3. Nowadays, to achieve sustainability is a fundamental principle when performing any activity including economic development, social development, and environmental 
protection. Based on the concept of sustainable development defined at Brundtland Commission, cost-benefit analysis, mainly involving land acquisition, investment and operation costs, energy consumption, ecological benefits, etc., has been considered as the major evaluation approach for sustainable development. The novel CWs have been successfully developed to strengthen the treatment performance. However, evaluation on $\mathrm{CW}$ sustainability has not been considered in those CWs involved. Hence, comparative analysis and evaluation of mass and energy flows for the reported CW strategies and techniques are needed for a deeper understanding of environmental and social sustainability. Furthermore, long-term cost-benefit analyses should be performed for successful application, which would also facilitate social acceptance of such $\mathrm{CW}$ techniques.

4. Given the increasingly strict water quality standards for wastewater treatments and water reuse worldwide, the successful applications of CWs are still a challenge when purifying particular compounds (such as heavy metals, emerging organic micropollutants, and selected risk elements) present in wastewaters. The current review indicates that some novel $\mathrm{CWs}$ have the potential to contribute to the removal of common pharmaceutical contaminants and heavy metals. Nevertheless, few data at present cannot provide very persuasive demonstrations for the performance and effectiveness of novel CWs in these applications. Thus, special attention should be paid to several aspects including the removal efficiencies of particular compounds during wastewater treatment in various intensified CWs, the removal mechanisms involved, the toxicity to CWs caused by the critical compounds, and the influences of certain important design and operation parameters.

5. The review shows that advances in the innovative design and operation of CWs have greatly increased contaminant removal efficiencies, thereby improving the sustainable applications of these treatment systems. For treatment wetlands, optimization and innovation in design, operation, and maintenance, which are the keys toward the sustainability of systems, could help to make this treatment technology much more attractive. Therefore, research efforts were made to develop novel enhancement technologies with a view to optimizing the removal performance. In addition, as longterm stability and sustainability of $\mathrm{CW}$ systems are dependent on the integrated management strategies, training for the operation and maintenance is a critical need to reinforce the sustainability of $\mathrm{CW}$ technology.

\section{Acknowledgments}

This work was supported by the CRSRI Open Research Program (Program SN: CKWV2015240/KY), the National Natural Science Foundation of China (21177075), the Program for New Century Excellent Talents in University (NCET-10-0554), and the fund from Shanghai Tongji Gao Tingyao Environmental Science \& Technology Development Foundation. 


\section{References}

Ayaz SC, Aktas O, Findik N, Akca L, Kinaci C (2012) Effect of recirculation on nitrogen removal in a hybrid constructed wetland system. Ecol Eng 40:1-5

Bilgin M, Simsek I, Tulun S (2014) Treatment of domestic wastewater using a lab-scale activated sludge/vertical flow subsurface constructed wetlands by using Cyperus alternifolius. Ecol Eng 70:362-365

Boog J, Nivala J, Aubron T, Wallace S, van Afferden M, Müller RA (2014) Hydraulic characterization and optimization of total nitrogen removal in an aerated vertical subsurface flow treatment wetland. Bioresour Technol 162:166-174

Brezinová T, Vymazal J (2015) Seasonal growth pattern of Phalaris arundinacea in constructed wetlands with horizontal subsurface flow. Ecol Eng 80:62-68

Butterworth E, Dotro G, Jones M, Richards A, Onunkwo P, Narroway Y, Jefferson B (2013) Effect of artificial aeration on tertiary nitrification in a full-scale subsurface horizontal flow constructed wetland. Ecol Eng 54:236-244

Cañizares P, Jiménez C, Martínez F, Sáez C, Rodrigo MA (2007) Study of the electrocoagulation process using aluminum and iron electrodes. Ind Eng Chem Res 46:6189-6195

Carty A, Scholz M, Heal K, Gouriveau F, Mustafa A (2008) The universal design, operation and maintenance guidelines for farm constructed wetlands (FCW) in temperate climates. Bioresour Technol 99: 6780-6792

Chang Y, Wu S, Zhang T, Mazur R, Pang C, Dong R (2014) Dynamics of nitrogen transformation depending on different operational strategies in laboratory-scale tidal flow constructed wetlands. Sci Total Environ 487:49-56

Chen Y, Wen Y, Cheng J, Xue CH, Yang DH, Zhou Q (2011) Effects of dissolved oxygen on extracellular enzymes activities and transformation of carbon sources from plant biomass: implications for denitrification in constructed wetlands. Bioresour Technol 102:24332440

Cui L, Ouyang Y, Gu W, Yang W, Xu Q (2013) Evaluation of nutrient removal efficiency and microbial enzyme activity in a baffled subsurface-flow constructed wetland system. Bioresour Technol 146:656-662

Dong H, Qiang Z, Li T, Jin H, Chen W (2012) Effect of artificial aeration on the performance of vertical-flow constructed wetland treating heavily polluted river water. J Environ Sci 24:596-601

Fan J, Wang W, Zhang B, Guo Y, Ngo HH, Guo W, Zhang J, Wu H (2013a) Nitrogen removal in intermittently aerated vertical flow constructed wetlands: impact of influent COD/N ratios. Bioresour Technol 143:461-366 
Fan J, Zhang B, Zhang J, Ngo HH, Guo W, Liu F, Guo Y, Wu H (2013b) Intermittent aeration strategy to enhance organics and nitrogen removal in subsurface flow constructed wetlands. Bioresour Technol 141:122-171

Fang Z, Song HL, Cang N, Li XN (2013) Performance of microbial fuel cell coupled constructed wetland system for decolorization of azo dye and bioelectricity generation. Bioresour Technol 144:165-171

Foladori P, Ruaben J, Ortigara AR (2013) Recirculation or artificial aeration in vertical flow constructed wetlands: a comparative study for treating high load wastewater. Bioresour Technol 149:398-405

Gao DW, Hu Q (2012) Bio-contact oxidation and greenhouse structured wetland system for rural sewage recycling in cold regions: a fullscale study. Ecol Eng 49:249-253

Hu YS, Zhao YQ, Zhao XH, Kumar JL (2012a) Comprehensive analysis of step feeding strategy to enhance biological nitrogen removal in alum sludge-based tidal flow constructed wetlands. Bioresour Technol 111:27-35

Hu Y, Zhao Y, Zhao X, Kumar JL (2012b) High rate nitrogen removal in an alum sludgebased intermittent aeration constructed wetland. Environ Sci Technol 46:4583-4590

Hua GF, Li L, Zhao YQ, Zhu W, Shen JQ (2013) An integrated model of substrate clogging in vertical flow constructed wetlands. J Environ Manag 119:67-75

Huang X, Liu C, Li K, Su J, Zhu G, Liu L (2015) Performance of vertical up-flow constructed wetlands on swine wastewater containing tetracyclines and tet genes. Water Res 70:109-117

Jia W, Zhang J, Wu J, Xie H, Zhang B (2010) Effect of intermittent operation on contaminant removal and plant growth in vertical flow constructed wetlands: a microcosm experiment. Desalination 262: 202-208

Ju X, Wu S, Zhang Y, Dong R (2014a) Intensified nitrogen and phosphorus removal in a novel electrolysis-integrated tidal flow constructed wetland system. Water Res 59:37-45

Ju X, Wu S, Huang X, Zhang Y, Dong R (2014b) How the novel integration of electrolysis in tidal flow constructed wetlands intensifies nutrient removal and odor control. Bioresour Technol 169:605-613

Lavrova S, Koumanova B (2010) Influence of recirculation in a lab-scale vertical flow constructed wetland on the treatment efficiency of landfill leachate. Bioresour Technol 101:1756-1761

Lee J, Lee K, Park K, Maeng S (2010) Hydrogenotrophic denitrification in a packed bed reactor: effects of hydrogen-to-water flow rate ratio. Bioresour Technol 101:3940-3946

Li F, Lu L, Zheng X, Ngo HH, Liang S, Guo W, Zhang X (2014a) Enhanced nitrogen removal in constructed wetlands: effects of dissolved oxygen and step-feeding. Bioresour Technol 169:395-402 
Li F, Lu L, Zheng X, Zhang X (2014b) Three-stage horizontal subsurface flow constructed wetlands for organics and nitrogen removal: effect of aeration. Ecol Eng 68:90-96

Lin Y, Jing S, Wang T, Lee D (2002) Effects of macrophytes and external carbon sources on nitrate removal from groundwater in constructed wetlands. Environ Pollut 119:413-420

Lin Y, Yin J, Wang J, Tian W (2012) Performance and microbial community in hybrid anaerobic baffled reactor-constructed wetland for nitrobenzene wastewater. Bioresour Technol 118:128-135

Lu S, Hu H, Sun Y, Yang J (2009) Effect of carbon source on the denitrification in constructed wetlands. J Environ Sci 21:1036-1043

Meng P, Pei H, Hu W, Shao Y, Li Z (2014) How to increase microbial degradation in constructed wetlands: influencing factors and improvement measures. Bioresour Technol $157: 316-326$

Nivala J, Hoos M, Cross C, Wallace S, Parkin G (2007) Treatment of landfill leachate using an aerated, horizontal subsurface-flow constructed wetland. Sci Total Environ 380:19-27

Nuengjamnong C, Chiarawatchai N, Polprasert C, Otterpohl R (2011) Treating swine wastewater by integrating earthworms into constructed wetlands. J Environ Sci Health, Part A: Tox Hazard Subst Environ Eng 46:800-804

Ong SA, Uchiyama K, Inadama D, Ishida Y, Yamagiwa K (2010) Performance evaluation of laboratory scale up-flow constructed wetlands with different designs and emergent plants. Bioresour Technol 101:7239-7244

Pei YS, Yang ZF, Tian BH (2010) Nitrate removal by microbial enhancement in a riparian wetland. Bioresour Technol 101:5712-5718

Peng J, Song Y, Liu Z, Gao H, Yu H (2012) Performance of a novel circular-flow corridor wetland toward the treatment of simulated high-strength swine wastewater. Ecol Eng 49:1-9

Prost-Boucle S, Molle P (2012) Recirculation on a single stage of vertical flow constructed wetland: treatment limits and operation modes. Ecol Eng 43:81-84

Puig S, Coma M, Desloover J, Boon N, Balaguer MD (2012) Autotrophic denitrification in microbial fuel cells treating low ionic strength waters. Environ Sci Technol 46:2309-2315

Rai UN, Tripathi RD, Singh NK, Upadhyay AK, Dwivedi S, Shukla MK, Mallick S, Singh SN, Nautiyal CS (2013) Constructed wetland as an ecotechnological tool for pollution treatment for conservation of Ganga river. Bioresour Technol 148:535-541

Rustige H, Nolde E (2007) Nitrogen elimination from landfill leachates using an extra carbon source in subsurface flow constructed wetlands. Water Sci Technol 56:125-133

Saeed T, Sun G (2011) A comparative study on the removal of nutrients and organic matter in wetland reactors employing organic media. Chem Eng J 171:439-447 
Saeed T, Sun G (2012) A review on nitrogen and organics removal mechanisms in subsurface flow constructed wetlands: dependency on environmental parameters, operating conditions and supporting media Environ Sci Pollut Res (2015) 22:14637-14650.

Saeed T, Sun G (2013) A lab-scale study of constructed wetlands with sugarcane bagasse and sand media for the treatment of textile wastewater. Bioresour Technol 128:438-447

Shao YY, Pei HY, Hu WR, Chanway CP, Meng PP, Ji Y, Li Z (2014) Bioaugmentation in lab scale constructed wetland microcosms for treating polluted river water and domestic wastewater in northern China. Int Biodeter Biodeg 95:151-159

Shen Z, Zhou Y, Liu J, Xiao Y, Cao R, Wu F (2015) Enhanced removal of nitrate using starch/PCL blends as solid carbon source in a constructed wetland. Bioresour Technol $175: 239-244$

Stefanakis AI, Akratos CS, Tsihrintzis VA (2011) Effect of wastewater step-feeding on removal efficiency of pilot-scale horizontal subsurface flow constructed wetlands. Ecol Eng 37:431-443

Sun G, Gray K, Biddlestone A, Allen S, Cooper D (2003) Effect of effluent recirculation on the performance of a reed bed system treating agricultural wastewater. Process Biochem 39:351-357

Sun G, Zhao Y, Allen S, Cooper D (2006) Generating "tide" in pilot-scale constructed wetlands to enhance agricultural wastewater treatment. Eng Life Sci 6:560-565

Sun G, Zhao YQ, Allen S (2007) An alternative arrangement of gravel media in tidal flow reed beds treating pig farm wastewater. Water Air Soil Poll 182:13-19

Tee HC, Lim PE, Seng CE, Nawi MAM (2012) Newly developed baffled subsurface-flow constructed wetland for the enhancement of nitrogen removal. Bioresour Technol 104:235-242

Tee HC, Lim PE, Seng CE, Mohd Nawi MA, Adnan R (2015) Enhancement of azo dye Acid Orange 7 removal in newly developed horizontal subsurface-flow constructed wetland. J Environ Manag 147:349-355

Verlicchi P, Zambello E (2014) How efficient are constructed wetlands in removing pharmaceuticals from untreated and treated urban wastewaters? A review. Sci Total Environ 470-471:1281-1306

Verlicchi P, Galletti A, Petrovic M, Barceló D, Al Aukidy M, Zambello E (2013) Removal of selected pharmaceuticals from domestic wastewater in an activated sludge system followed by a horizontal subsurface flow bed-analysis of their respective contributions. Sci Total Environ 1:454-455

Villaseñor J, Capilla P, Rodrigo MA, Cañizares P, Fernández FJ (2013) Operation of a horizontal subsurface flow constructed wetland - microbial fuel cell treating wastewater under different organic loading rates. Water Res 47:6731-6738 
Vymazal J (2011) Constructed wetlands for wastewater treatment: five decades of experience. Environ Sci Technol 45:61-69 Vymazal J (2013) The use of hybrid constructed wetlands for wastewater treatment with special attention to nitrogen removal: a review of a recent development. Water Res 47:4795-4811

Vymazal J (2014) Constructed wetlands for treatment of industrial wastewaters: a review. Ecol Eng 73:724-751

Vymazal J, Kröpfelová L, Svehla J, Stíchová J (2010) Can multiple harvest of aboveground biomass enhance removal of trace elements in constructed wetlands receiving municipal sewage? Ecol Eng 36: 939-945

Wallace S, Parkin G, Cross C (2001) Cold climate wetlands: design \& performance. Water Sci Technol 44:259-265

Wang R, Korboulewsky N, Prudent P, Domeizel M, Rolando C, Bonin G (2010) Feasibility of using an organic substrate in a wetland system treating sewage sludge: impact of plant species. Bioresour Technol 101:51-57

Wang W, Gao J, Guo X, Li W, Tian X, Zhang R (2012) Long term effects and performance of two-stage baffled surface flow constructed wetland treating polluted river. Ecol Eng 49:93-103

Wang Z, Dong J, Liu L, Zhu G, Liu C (2013) Screening of phosphate removing substrates for use in constructed wetlands treating swine wastewater. Ecol Eng 54:57-65

Wang C, Zhang M, Ye M, Wang J, Li G (2014a) Pilot-scale electrochemical oxidation combined with constructed wetland system for unconventional surface water treatment. J Chem Technol Biotechnol 89: 1599-1606

Wang Z, Liu C, Liao J, Liu L, Liu Y, Huang X (2014b) Nitrogen removal and N2O emission in subsurface vertical flow constructed wetland treating swine wastewater: effect of shunt ratio. Ecol Eng 73:446- 453

Wu H, Zhang J, Li P, Zhang J, Xie H, Zhang B (2011a) Nutrient removal in constructed microcosm wetlands for treating polluted river water in northern China. Ecol Eng 37:560 568

Wu S, Austin D, Liu L, Dong R (2011b) Performance of integrated household constructed wetland for domestic wastewater treatment in rural areas. Ecol Eng 37:948-954

Wu S, Zhang D, Austin D, Dong R, Pang C (2011c) Evaluation of a labscale tidal flow constructed wetland performance: oxygen transfer capacity, organic matter and ammonium removal. Ecol Eng 37: 1789-1795

Wu L, Li X, Song H, Wang G, Jin Q, Xu X, Gao Y (2013) Enhanced removal of organic matter and nitrogen in a vertical-flow constructed wetland with Eisenia foetida. Desalin Water Treat 78:7460-7468 
Wu S, Kuschk P, Brix H, Vymazal J, Dong R (2014) Development of constructed wetlands in performance intensifications for wastewater treatment: a nitrogen and organic matter targeted review. Water Res 57C:40-55

Wu H, Zhang J, Ngo HH, Guo W, Hu Z, Liang S, Fan J, Liu H (2015a) A review on the sustainability of constructed wetlands for wastewater treatment: design and operation. Bioresour Technol 175:594-601

Wu H, Fan J, Zhang J, Ngo HH, Guo W, Hu Z, Liang S (2015b) Decentralized domestic wastewater treatment using intermittently aerated vertical flow constructed wetlands: impact of influent strengths. Bioresour Technol 176:163-168

Xu DF, Li YX, Howard A, Guan YD (2013a) Effect of earthworm Eisenia fetida and wetland plants on nitrification and denitrification potentials in vertical flow constructed wetland. Chemosphere 92: 201-206

Xu DF, Li YX, Howard A (2013b) Influence of earthworm Eisenia fetida on removal efficiency of $\mathrm{N}$ and $\mathrm{P}$ in vertical flow constructed wetland. Environ Sci Pollut Res 20:5922-5929

Yadav AK, Dash P, Mohanty A, Abbassi R, Mishra BK (2012) Performance assessment of innovative constructed wetlandmicrobial fuel cell for electricity production and dye removal. Ecol Eng 47:126-131

Yan Y, Xu J (2014) Improving winter performance of constructed wetlands for wastewater treatment in northern China: a review. Wetlands 34:243-253 Ye F, Li Y (2009) Enhancement of nitrogen removal in towery hybrid constructed wetland to treat domestic wastewater for small rural communities. Ecol Eng 35:1043-1050

Zhai X, Piwpuan N, Arias CA, Headley T, Brix H (2013) Can root exudates from emergent wetland plants fuel denitrification in subsurface flow constructed wetland systems. Ecol Eng 61:555-563

Zhang DQ, Tan SK, Gersberg RM, Zhu J, Sadreddini S, Li Y (2012) Nutrient removal in tropical subsurface flow constructed wetlands under batch and continuous flow conditions. J Environ Manag 96:1-6

Zhao YQ, Sun G, Allen SJ (2004) Purification capacity of a highly loaded laboratory scale tidal flow reed bed system with effluent recirculation. Sci Total Environ 330:1-8

Zhao Y, Collum S, Phelan M, Goodbody T, Doherty L, Hu Y (2013) Preliminary investigation of constructed wetland incorporating microbial fuel cell: batch and continuous flow trials. Chem Eng J 229: 364-370 Environ Sci Pollut Res (2015) 22:14637-14650 14649

Zhao C, Xie H, Mu Y, Xu X, Zhang J, Liu C, Liang S, Ngo HH, Guo W, Xu J, Wang Q (2014) Bioremediation of endosulfan in laboratoryscale constructed wetlands: effect of bioaugmentation and biostimulation. Environ Sci Pollut Res 21:12827-12835 
Zhi W, Ji G (2014) Quantitative response relationships between nitrogen transformation rates and nitrogen functional genes in a tidal flow constructed wetland under $\mathrm{C} / \mathrm{N}$ ratio constraints. Water Res 64:32-41

Zhu D, Sun C, Zhang H, Wu Z, Jia B, Zhang Y (2012a) Roles of vegetation, flow type and filled depth on livestock wastewater treatment through multi-level mineralized refusebased constructed wetlands. Ecol Eng 39:7-15

Zhu J, Hu W, Hu L, Deng J, Li Q, Gao F (2012b) Variation in the efficiency of nutrient removal in a pilot-scale natural wetland. Wetlands 32:311-319 